\title{
A PHOTOBIOREACTOR FOR MICROALGAE-BASED WASTEWATER TREATMENT
}

\author{
${ }^{1,2}$ National Aviation University, Liubomyra Huzara Avenue 1, 03058, Kyiv, Ukraine \\ E-mails: ${ }^{1}$ lenyo@ukr.net, ${ }^{2}$ shamanskiy_s_i@ukr.net
}

\begin{abstract}
Purpose and Objectives of the Work. This scientific article is devoted to creation of an advanced photobioreactor design for wastewater treatment from biogenic compounds. Research Methods are based on a systematic analysis of theoretical research, synthesis, anology and comparison. Research Results. As a result, the improved photobioreactor design was proposed, in which the application of new elements and connections reduces the required area for its placement, immobilization of microalgae in the working area and, as a result, reducing the working area, the ability to quickly replace the sleeves of the working area, covered with sediment inside, and, as a result, reduce labor costs and downtime of the photobioreactor. Discussion. The problem is solved by the fact that the photobioreactor is made in the form of a transparent flowing rectangular open-topped tank, inside of which are vertically attached to the bottom of the tank by quick-release fasteners transparent flowing flexible hoses, to which at the bottom by means of non-return valves are connected pipelines for wastewater and microalgae supply and tubes for carbon dioxide supply and are connected by means of shut-off valves pipelines for drainage of a mixture of microalgae with residual wastewater, and in the upper hermetic part, where there are valves for drainage of accumulated gases, while the pipeline for the purified wastewater discharge is connected to a guide tray purified wastewater supply inside of a flowing rectangular open-topped tank, and at the outlet of the pipeline for drainage of a mixture of microalgae with residual wastewater is a microalgae separator to separate return and excess biomass. Conclusion. The proposed construction of photobioreactor can have good perspectives to be use in communal services for sewage water purification from biogenic compounds.
\end{abstract}

Keywords: photobioreactor, microalgae, biogenic compounds, wastewater treatment.

\section{Introduction}

Almost all modern technologies are unnatural and destructive in contrast to natural processes that are not harmless to the environment. Growing environmental problems are increasingly affecting the development of waste-free technologies. From the point of view of modern technologies, biological systems are a kind of record-breakers, because a living cell produces more substance than any other enterprise. Recently are rapidly evolving biotechnologies, which uses photoautotrophs - organisms for the existence of which is enough only simple substances and energy of sunlight, in particular microalgae [1].

\section{Analysis of the latest research and publications, problem statement}

Microalgae are a wide group of photosynthetic organisms. They can to develop in difficult agroclimatic conditions and to produce a number of useful ones' products: fats, proteins, carbohydrates, dyes, biologically active compounds, etc. Special of interest is the use of microalgae as organisms capable of storing solar energy through photosynthesis, because the efficiency of energy conversion microalgae is much higher than higher plants. Microalgae are a great biological resource. They are used in various branches of science and technology [2]. There is increasing commercial interest in the cultivation of microalgae for the production of biofuels, foods, pharmaceuticals, and wastewater treatment. Due to microalgae natural metabolism, they are efficient absorbers of nutrients and carbon dioxide, while increasing their biomass. Excessive nutrients must be efficiently removed to prevent eutrophication [3].

Microalgae have many advantages, such as a high photosynthetic efficiency, a rapid growth rate, simple methods for cultivation, and the ability to be cultivated on sterile land $[4,5]$.

The biomass of many strains of microalgae can be used to manufacture many types of products [6]. When 
using this method of wastewater treatment at municipal treatment plants, excess biomass can be directly processed into biogas at treatment plants [7-10]. This can be done in methane tanks together with excess activated sludge. Biomass can also be processed into liquid motor biofuels of the third generation, or into phosphate and nitrate fertilizers [11-14].

There are phototropic, heterotrophic and myxotrophic feeding methods of microalgae. Phototrophic method is based on obtaining the required energy by photosinthesis. The source of carbon for phototrophic organisms is, basically, carbon dioxide. Heterotrophic method is determined by obtaining energy by consuming organic matter. Mixotrophic method is a combination of the two previous methods [15].

Photoautotrophic microalgae can be grown in open or closed photobioreactors. Reactors can be operated in continuous, batch or semi-continuous mode and can be installed indoors or outdoors.

In the photoautotrophic cultivation of microalgae, the light source may be provided by the sun or an artificial light source. Sunlight is free and abundant, and its use avoids the necessity for investment or electricity costs. But light intensity in outdoor cultivation varies with the day/night cycle, changing weather conditions, and with seasonal changes [16]. The fluctuations in sunlight can be avoided by the application of artificial light sources. Artificial light sources are stable and controllable. The light utilization efficiency and biomass productivity of algal cells are usually higher under artificial light sources compared with natural sunlight. In addition, the use of an artificial light source allows for more choices in location. However, the capital investment and operation costs are high and lead to higher final production costs. In one study [16], it was calculated that production costs increased by 25.3 $\$ \mathrm{~kg}^{-1}$ (dry-weight biomass) with the use of an artificial light source. In addition, the energy balance is negative with the application of artificial light due to the energy losses in luminaries and energy fixation.

Open ponds were constructed for growing microalgae as a food supplement during World War II. [17]. Natural waters (ponds, lakes, lagoons) and artificial ponds, or open top vessels, are constructed outdoors or in green houses and can be used as open photobioreactors. Typically, open systems are designed and constructed with very shallow depths to facilitate efficient light penetration through the growth medium.

Although the open systems are easy to construct and operate, poor light utilization by the algae cells, evapo-rative losses, dispersion of $\mathrm{CO}_{2}$ to the atmosphere and large land area requirement adversely affect their technical and economic feasibility. Contamination by predators and other fast growing heterotrophic microorganisms further limit algae production in open systems to only those organisms that can grow under extreme conditions. Poor mixing also can be an issue for open systems resulting in low mass transfer rates and consequently lower biomass productivity. Sizes of the commercial ponds vary depending on land availability and production capacity. Raceway type ponds usually cover $1000-5000 \mathrm{~m}^{2}$. The maximum productivity of the open ponds is quite low at $0.5-0.7 \mathrm{~g}$ dry algal biomass/L growth medium [17].

In the paper [18], a design of an open bioreactor for the cultivation of microalgae was proposed. The main feature of this design is a cascade type of tank, which allows you to satisfy parameters such as lightness, mixing, energy efficiency, and economical. According to the proposed methodology of efficiency estimation received that this bioreactor construction is efficient on $85 \%$ and offset during the year is positive [18].

There are photobioreactors of varioys design. Photobioreactors, shaped in the form of open troughs with a relatively thin layer of water in which algar are placed. Despite their advantages (the possibility to create an optimal environment for cultivating, efficient mixing, automation etc.), they have a number of disadvantages inherent inwater bodies (for example adverse weather conditions).

Photobioreactors, shaped in the form of transparent flasks and tubes filled with cultivatingedium and algae. Such installations are less sensitive to weather conditions, but have other disadvantages. Access to the light required for photosynthesis through transparent walls is complicated over time due to plague on the walls, which is formed inside, and the mass of microalgae near the walls also complicates the passage of light inside, as the number of microalgae increases 
$[19,20]$.

Photobioreactors, shaped in the form of large tanks made out of transparent material. In general, they usually need artifial ligtining because light doesn't penentrate well into the thickness of microalgae, even when mixing takes place [20].

Photobioreactors, shaped in the form of pyramidical containers, which are open horizontal troughs with cultivating medium and algae, located in a pyramidicac body of transparent material. Given the advantages inherent in open troughs, these installations are not significantly affected by adverse weather factors. However, the dishadvantage of such installations may be certain technological problems with the saturation of the environment with carbon dioxide and its efficient use, as well as problems with ensuring the continuity of the cultivation process [20].

Closed systems can be categorized according to the geometrical configuration (i.e. tubular, flat panel, conical etc.) and orientation of the vessels (horizontal, vertical or inclined), the systems use for circulating and illuminating the culture and the gas exchange, the arrangement of the individual growth units/reactors (series or parallel) and the materials of construction (glass, plastic).

The following factors need to be considered during the reactor design [17]:

a) effective and efficient illumination,

b) proper $\mathrm{CO}_{2}$ supply with minimum losses,

c) removal of photosynthetically generated oxygen that may inhibit cell growth,

d) scalability of the reactor design.

Due to the high cost of construction and operation, the closed systems are mostly used for the production of high value products.

Some processing parameters such as nutrient supply can easily be controlled in a closed reactor. Solar radiation is more difficult to regulate. In dense cultures large number of cells impede light penetration and absorption. This phenomenon is known as "selfshading."

The Table 1 demonstrates advantages and disadvantages of opened and closed systems application.
Comparative analysis of opened and closed systems for biomass productivity

\begin{tabular}{|c|c|}
\hline Advantages & Disadvantages \\
\hline $\begin{array}{l}\text { Higher biomass } \\
\text { productivity in closed } \\
\text { systems ( } 40-75 \text { and } 250- \\
365 \text { metric tons of dry } \\
\text { algae/hectare-year in open } \\
\text { and closed systems, } \\
\text { respectively). }\end{array}$ & $\begin{array}{l}\text { Higher capital cost of } \\
\text { closed systems as } \\
\text { compared to the open } \\
\text { ones. }\end{array}$ \\
\hline $\begin{array}{l}\text { Flexibility in algae strain } \\
\text { selection for closed } \\
\text { systems. }\end{array}$ & $\begin{array}{l}\text { Large land requirement for } \\
\text { open ponds. }\end{array}$ \\
\hline $\begin{array}{l}\text { Closed systems have } \\
\text { longer cultivation period } \\
\text { than the open systems. }\end{array}$ & $\begin{array}{l}\text { Difficulty in maintaining } \\
\text { monocultures in open } \\
\text { systems. }\end{array}$ \\
\hline & $\begin{array}{l}\text { Difficulty in controlling } \\
\text { the process parameters } \\
\text { (water evaporation rates, } \\
\text { contamination etc.) in } \\
\text { open systems. }\end{array}$ \\
\hline & $\begin{array}{l}\text { Fouling of the reactor } \\
\text { reducing light availability } \\
\text { to the cells, consequently } \\
\text { lowering biomass } \\
\text { productivity in closed } \\
\text { systems. }\end{array}$ \\
\hline & $\begin{array}{l}\text { Difficulty in controlling } \\
\text { the temperature in closed } \\
\text { systems that are built } \\
\text { outside the moderate } \\
\text { climate zones. }\end{array}$ \\
\hline & $\begin{array}{l}\text { Relatively small } \\
\text { illuminated area to volume } \\
\text { ratio in closed systems as } \\
\text { compared to open ponds. }\end{array}$ \\
\hline
\end{tabular}

\section{Purpose and objectives of the work}

The purpose of this article is to develop a photobioreactor design for wastewater treatment from biogenic compounds, in which the application of new elements and connections reduces the required area for its placement, immobilization of microalgae in the working area and, as a result, reducing the working area, the ability to quickly replace the sleeves of the working area, covered with sediment inside, and, as a result, reduce labor costs and downtime of the photobioreactor. 


\section{Methods of research}

Research methods are based on a systematic analysis of theoretical research, synthesis, anology and comparison.

\section{Research results}

The problem is solved by the fact that the photobioreactor is made in the form of a transparent flowing rectangular open-topped tank, inside of which are vertically attached to the bottom of the tank by quick-release fasteners transparent flowing flexible hoses, to which at the bottom by means of non-return valves are connected pipelines for wastewater and microalgae supply and tubes for carbon dioxide supply and are connected by means of shut-off valves pipelines for drainage of a mixture of microalgae with residual wastewater, and in the upper hermetic part, where there are valves for drainage of accumulated gases, while the pipeline for the purified wastewater discharge is connected to a guide tray purified wastewater supply inside of a flowing rectangular open-topped tank, and at the outlet of the pipeline for drainage of a mixture of microalgae with residual wastewater is a microalgae separator to separate return and excess biomass.

The Fig. 1 shows a general diagram of photobioreactor for wastewater treatment from nutrients, which consists of a housing 12 made in the form of a transparent flowing rectangular open-topped tank, through which flows treated with microalgae wastewater. Inside the housing 12, transparent flexible sleeves 8 are vertically attached to the bottom by quick-release fasteners so that they are completely immersed in the treated wastewater flowing through the inner tank of the housing. In the upper parts of the transparent flexible sleeves are fixed floats 9 to support them in the water in a vertical position. In the lower parts of the transparent flexible hoses are installed check valves 15, to which are connected branches from the sewage supply pipe 10 . At the inlet of the sewage supply pipe 10 in the housing 12 is a pump for pumping sewage 1 . Also in the lower parts of transparent flexible hoses 16 check valves are installed, to which are connected branches from the carbon supply pipe 11 . At the inlet of the carbon pipe 11 in the housing 12 is a compressor for injecting carbon dioxide 2 from the carbon dioxide tank 3 . In the bottom of the housing are mounted elements of shut-off valve 7 , to which are connected branches from microalgae discharge pipe 14. At the outlet of the microalgae discharge pipe from the housing 12 is installed a microalgae separator 17 . To the microalgae separator is connected the pipeline of excess biomass and the pipeline of return biomass 19, which is connected to the tank with microalgae 5 and the injection pump of microalgae 4 . In the upper parts of the transparent flexible sleeves are mounted nipples 6 , to discharge gases that accumulate in the transparent flexible sleeves. Also connected to the upper parts of the transparent flexible hoses is a branch from the purified wastewater discharge pipe 13 , to which the return pipe of the purified wastewater 18 is connected. In the inlet part of the housing 12 there is a distribution tray 20 to which the return pipe of the purified wastewater is connected. the housing 12 houses a prefabricated tray 21 , to which is connected a drainage tray 22 .

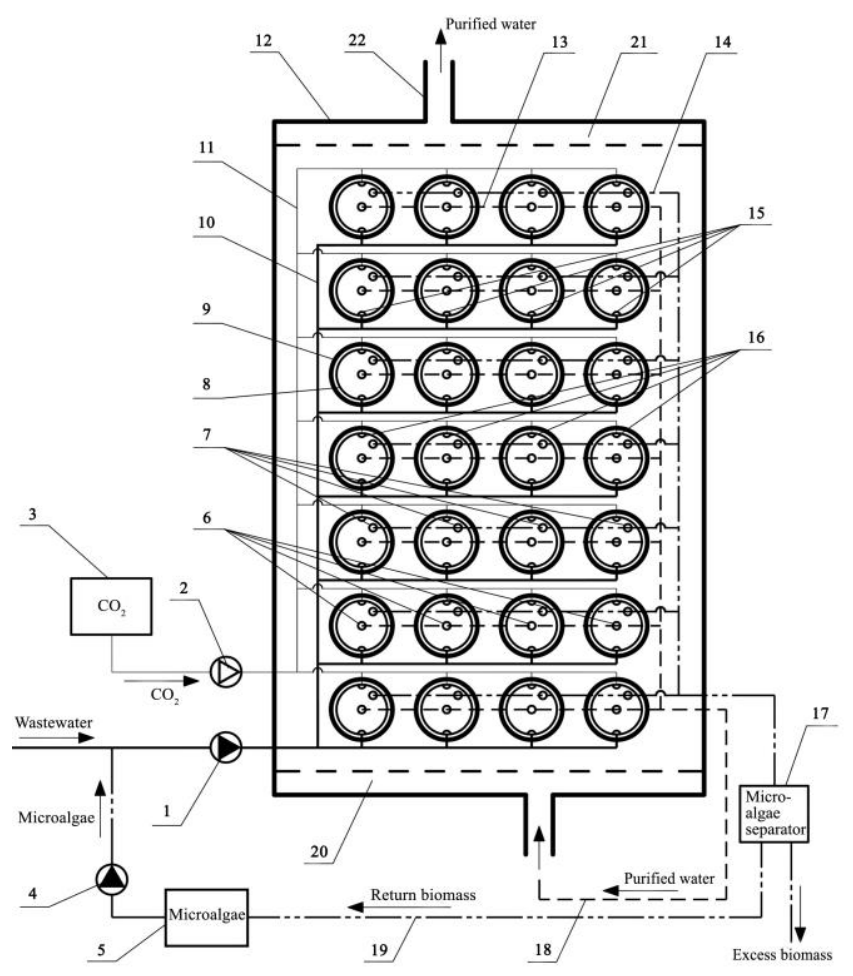

Fig. 1. Scheme of photobioreactor for wastewater treatment from biogenic compounds

\section{Discussion}

The photobioreactor for wastewater treatment works as follows.

Housing 12 is located in an open area with natural direct sunlight. The cycle of the photobioreactor is divided 
into three stages: the start stage; the stage of wastewater treatment; the stage of completion of the cycle.

At the start stage, the housing 12 is filled with clarified water so that the transparent flexible sleeves 8 attached to the bottom of the housing with the floats 9 attached to their upper parts are in a vertical position. The preclarified wastewater to be treated is mixed with microalgae from a tank 5 pumped by a microalgae injection pump 4. The mixture is then fed to the wastewater supply pipe 10 by means of a wastewater injection pump 1. It is distributed between the branches from this pipeline. transparent flexible sleeves 8 . Through the check valves 15 , the mixture is fed into the lower parts of the inner tanks of the flexible transparent sleeves until they are completely filled. After that, the supply of microalgae from the tank 5 is stopped.

In the treatment step, the wastewater is continuously fed to the wastewater supply pipe 10 by means of a wastewater injection pump 1 and enters the lower parts of the inner tanks of the flexible transparent hoses through a branch with non-return valves 15 . The wastewater moves from the bottom upwards inside the transparent flexible hoses and in their upper part is drained by the pipeline of treated wastewater 13 . The speed of vertical movement of wastewater is selected so that the microalgae inside the transparent flexible hoses 8 are in a suspended state, remain inside the internal tanks and are not carried away with water. At the same time, carbon dioxide from the tank 3 is fed into the transparent flexible hoses by means of a compressor 2 and a pipe 11 through the nipples 16 mounted in their lower parts. Part of the carbon dioxide dissolves in wastewater and becomes a carbon source for microalgae metabolism. The other part, which does not have time to dissolve in water, together with other gaseous products, is removed through the nipple 6 into the environment. During the movement of wastewater in the sleeves, due to the metabolism of microalgae there is an increase in their biomass and a simultaneous decrease in the concentration of nutrients in wastewater. The treated wastewater is collected by pipe 13 and through the guide tray 20 is fed into the inner tank 12. Due to the many outlets, the distribution tray 20 evenly distributes the flow of treated wastewater across the width of the housing 12 . Wastewater flowing through the inner tank completely covers transparent flexible hoses in a vertical position due to floats 9 . After flowing through the inner tank of the housing 12 at its opposite end, the treated wastewater is collected by the

collecting tray 21 and removed from the
photobioreactor by a drain tray 22. Due to the fact that flexible hoses with microalgae, cultivated is constantly immersed in running treated wastewater, increases the temperature inertia of the photobioreactor and achieves better temperature stabilization of the cultured microalgae in the cold season. In the warm season, due to the scattering of direct sunlight passing through the treated wastewater, the intensity of illumination of microalgae by direct sunlight decreases, which weakens the phenomenon of photoinhibition of microalgae metabolism.

At the stage of completion of the cycle of wastewater supply by pump 1 is stopped. The mixture of microalgae with wastewater through the elements of the shut-off valve 7 is discharged from the transparent flexible sleeves and through the drainage pipe of microalgae 14 is fed into the microalgae separator 17 , where the separation of recirculated biomass from excess. The recirculated biomass is piped to the microalgae tank 5 , and the excess biomass is discharged through the excess biomass discharge pipe and is a raw material for the production of marketable products (biofuels, biofertilizers, etc.).

After losing the transparency of the flexible sleeves 8 at the end of the cycle, the inner capacity of the housing 12 is emptied, attached to the bottom of the housing with quick-release fasteners flexible sleeves are disconnected and replaced with new or previously cleaned. Cleaning is performed outside the housing outside the operating cycle.

\section{Conclusions}

The proposed construction of photobioreactor can have good perspectives to be use in communal services for sewage water purification from biogenic elements. It also can be used in sewage systems of different enterprises of different branches of industry, when it is necessary to purify sewage water.

\section{References}

[1] Zolotar'ova, O. K., Shnyukova, YE. I., Syvash, O. O., \& Mykhaylenko, N. F. (2008). Perspektyvy vykorystannya mikrovodorostey u biotekhnolohiyi. Available at:

http://botany.kiev.ua/doc/zolot_monog_2008.pdf (in Ukrainian)

[2] Shamanskyi S. I. Boichenko S. V. (2018). Innovative Environmentally Friendly Technologies in 
Sewarage. Monograph. Kyiv: Publishing House «Center for Educational Literature», $320 \mathrm{p}$.

[3] Jing-Han Wang, Tian-Yuan Zhang, Guo-Hua Dao, Xue-Qiao Xu, Xiao-Xiong Wang, Hong -Ying $\mathrm{Hu}$ (2017). Microalgae-based advanced municipal wastewater treatment for reuse in water bodies Appl. Microbiol. Biotechnol. Vol. 101(7): pp. 2659-2675. doi: 10.1007/s00253-017-8184-x.

[4] Walker T.L., Purton S., Becker D.K., Collet C. (2005). Microalgae as bioreactors. Plant Cell Rep. Vol.24, pp.629-641.

[5] Chiu S.Y., Kao C.Y., Tsai M.T., Ong S.C. et al. (2009). Lipid accumulation and $\mathrm{CO}_{2}$ utilization of Nannochloropsisoculata in response to $\mathrm{CO}_{2}$ aeration. Bioresour. Technol. Vol.100, pp. 833-838.

[6] Naruka M., Khadka M., Upadhayay S., Kumar S. (2019). Potential Applications Of Microalgae In Bioproduct Production: A Review. Octa Journal of Biosciences. Vol. 7 No. 1, pp. 1-5.

[7] Magdalena J. A., Llamas M., Tomas-Pejy E. and Gonzalez-Fernandez C. (2019). Semicontinuous anaerobic digestion of protease pretreated Chlorella biomass for volatile fatty acids production. Journal of Chemical Technoljgy and Biotechnology. Vol. 94, pp. 1861-1869. doi: 10.1002/jctb.5960.

[8] Głowacka N., Gaduš J. (2019). Verification of the Green Microalgae Biomass Use for Biogas. Acta Regionalia et Environmentalica. Vol.1, pp. 15-49. doi: 10.2478/aree-2019-0004.

[9] Gonzalez Fernandez C., Barreiro Vescovo S., de Godos I., Fernandez M., Zouhayr A. and Ballesteros M. (2018). Biochemical methane potential of microalgae biomass using different microbial inocula. Biotechnology for Biofuels, Vol.11:184, pp. 1-11. doi: 10.1186/s13068-018-1188-7.

[10] Koyandea A. K., Show P. L., Guob R., Tangc B., Oginod C. and Chang J. S. (2019). Bio-processing of algal bio-refinery: a review on current advances and future Perspectives. Bioengineered. Vol. 10 No. 1, pp.574-592.doi: 10.1080/21655979.2019.1679697

[11] Milledge J. J., Nielsen. V., Maneein S. and Harvey P. J. (2019). A Brief Review of Anaerobic
Digestion of Algae for Bioenergy. Energies. Vol.12, 22 p.

[12] Raheem A., Prinsen P., Vuppaladadiyam A. K., Zhao M., Luque R. (2018). A review on sustainable microalgae based biofuel and bioenergy production: Recent developments. Journal of Cleaner Production. Vol.181, pp. 42-59. doi:10.1016/j.jclepro.2018.01.125.

[13] Bhagea R., Bhoyroo V., Puchooa D. (2019). Microalgae: the next best alternative to fossil fuels after biomass. A review Microbiology Research. Vol. 10:7936, pp. 12-23. doi:10.4081/mr.2019.7936.

[14] Saad M. G., Dosoky N. S., Zoromba M. S. and Shafik H. M. (2019). Algal Biofuels: Current Status and Key Challenges. Energies. Vol.12, pp. 1920. doi: 10.3390/en12101920.

[15] S. Shamanskyi, S. Boichenko, L. Pavliukh (2018). Estimating of microalgae cultivation productivity for biofuel production in Ukraine conditions. Proceedings of the National Aviation University. Vol.3 (76), pp.67-77.

[16] Blankena W., Cuaresma M., Wijffels R. H., Janssen M. (2013). Cultivation of microalgae on artificial light comes at a cost. Algal Res. Vol.2, pp. 333-340.

[17]https://extension.okstate.edu/factsheets/photobi oreactor-design-for-algal-biomass-production.html.

[18] Pavliukh L., Boichenko S., Shamansky S., Syrotina I., Todorovych O. (2020). Cascade Photobioreactor for Waste Water Treatment by Microalgae. Modern Management Review, Vol. XXV No 27 (3/2020), pp. 17-29.

[19] S. Shamanskyi, S. Boichenko, Adeniyi C. Photobioreactor for microalgae cultivation for biofuel production with simulteniuos sewage water treatment (2019). Systemy i srodki transport: monograph. No 16, pp. 61-67.

[20] Shamanskyi Sergii, Boichenko Sergii, Pavliukh Lesia (2020). Wastewater treatment with bioconversion for motor fuel production in Ukraine. Bezpieczenstwo I materialy eksploatacyjne: Systemy i srodki transport: monograph. No 20, pp. 27-33.

\section{Л. І. Павлюх ${ }^{1}$, С.Й. Шаманський ${ }^{2}$ Фотобіореактор для очищення стічних вод на основі мікроводоростей \\ ${ }^{2}$ Національний авіаційний університет, просп. Любомира Гузара, 1, Київ, Україна, 03058 \\ E-mails: ${ }^{1}$ lenyo@ukr.net; ${ }^{2}$ shamanskiy_s_i@ukr.net}


Мета і завдання роботи. Ця наукова стаття присвячена створенню вдосконаленої конструкції фотобіореактора для очищення стічних вод від біогенних сполук. Методи дослідження засновані на систематичному аналізі теоретичних досліджень, синтезі, аналогії та порівнянні. Результати досліджень. В результаті було запропоновано вдосконалену конструкцію фотобіореактора, при якій застосування нових елементів та з'єднань зменшує необхідну площу для його розміщення, іммобілізації мікроводоростей в робочій зоні і, як результат, зменшення робочої зони, здатність швидко замінити рукави робочої зони, покриті осадом з середини, i, як результат, зменшити трудові витрати та час простою фотобіореактора. Обговорення. Проблема вирішується тим, що фотобіореактор виконаний у вигляді прозорої проточного прямокутної ємності з відкритим верхом, всередині якої вертикально розташовані, прикріплені до днища ємності швидкорозємними кріпленнями, прозорі проточні гнучкі рукави, до яких у нижній частині через зворотні клапани під'єднані трубопроводи подачі стічної води і мікроводоростей, трубки для подачі вуглекислого газу та під'єднані через запірну арматуру трубопроводи для відведення суміші мікроводоростей із залишковою стічною водою, а у верхній герметичній частині під'єднані трубопроводи для відведення очищеної стічної води, у місці приєднання яких розташовані клапани для випускання накопичуваних газів, при цьому трубопровід для відведення очищеної стічної води приєднано до направляючого лотка для подачі очищеної стічної води у середину прямоточної прямокутної ємності 3 відкритим верхом, з'єднаний з направляючим лотком для подачі очищених стічних вод посередині проточного прямокутного резервуара з відкритим верхом, а на виході трубопроводу для відведення суміші мікроводоростей із залишковою стічною водою розташований сепаратор мікроводоростей для розділення зворотної та надлишкової біомаси. Висновки. Запропонована конструкція фотобіореактора може мати хороші перспективи для використання в комунальних службах для очищення стічних вод від біогенних елементів.

Ключові слова: фотобіореактор, мікроводорості, біогенні сполуки, очищення стічних вод.

Л.И. Павлюх ${ }^{1}$, С.Й. Шаманский ${ }^{2}$ Фотобиореактор для очистки сточных вод на основе микроводорослей

${ }^{2}$ Национальный авиационный университет, просп. Любомира Гузара, 1, Киев, Украина, 03058

E-mails: ${ }^{1}$ lenyo@ukr.net; ${ }^{2}$ shamanskiy_s_i @ukr.net

Цель и задачи работы. Эта научная статья посвящена созданию усовершенствованной конструкции фотобиореактора для очистки сточных вод от биогенных соединений. Методы исследования основанные на систематическом анализе теоретических исследований, синтезе, аналогии и сравнении. Результаты исследований. В результате было предложено усовершенствованную конструкцию фотобиореактора, при которой применение новых элементов и соединений уменьшает необходимую площадь для его размещения, иммобилизации микроводорослей в рабочей зоне и, как результат, уменьшение рабочей зоны, способности к быстро заменить гильзы рабочей зоны, покрытые осадком с середины и, как результат, уменьшить трудовые затраты и время простоя фотобиореактора. Обсуждение. Проблема решается тем, что фотобиореактор выполнен в виде прозрачной проточной прямоугольной емкости с открытым верхом, внутри которой вертикально расположенные прикреплены к днищу емкости быстроразъемными креплениями прозрачные проточные гибкие рукава, в которых в нижней части через обратные клапаны подключены трубопроводы подачи сточной воды и микроводорослей, трубки для подачи углекислого газа и подключены через запорную арматуру трубопроводы для отвода смеси микроводорослей с остаточной 
сточной водой, а в верхней герметичной части подсоединены трубопроводы для отвода очищенных сточных вод, в месте присоединения которых расположены клапаны для выпуска накапливаемых газов, при этом трубопровод для отвода очищенной сточной воды присоединен к направляющиму лотку для подачи очищенной сточной воды внутрь прямоточной прямоугольной емкости с открытым верхом, соединен с направляющим лотком для подачи очищенных сточных вод во внутрь проточной прямоугольной емкости с открытым верхом, а на выходе трубопровода для отвода смеси микроводорослей с остаточной сточной водой расположен сепаратор микроводорослей для разделения обратной и избыточной биомассы. Выводы. Предложенная конструкция фотобиореактора может иметь хорошие перспективы для использования в коммунальных службах для очистки сточных вод от биогенных элементов.

Ключевые слова: фотобиореактор, микроводоросли, биогенные соединения, очистка сточных вод.

Lesia Pavliukh (1982). Candidate of Engineering. Associate Professor.

Associate Professor of the Ecology Department, Faculty of Environmental Safety, Engineering and Technologies, National Aviation University, Kyiv, Ukraine.

Education: Environmental Protection Faculty, National Aviation University, Kyiv, Ukraine (2005).

Research area: waste management.

Publications: more than 80.

E-mail: lenyo@ukr.net

Sergii Shamanskyi (1971). Doctor of Engineering. Associate Professor.

Senior Researcher of the scientific group of the Chemistry and Chemical Technology Department, Faculty of Environmental Safety, Engineering and Technologies, National Aviation University, Kyiv, Ukraine.

Education: Engineering Faculty, Vinnytsia State Technical University, Vinnytsia, Ukraine (1995).

Research area: wastewater treatment.

Publications: more than 100.

E-mail: shamanskiy_s_i@ukr.net 